\title{
THE IMPROVEMENT OF CIVIL CONSCIOUSNESS OF LAW FOR THE ENDORSEMENT OF LAW AND ECONOMIC DEVELOPMENT IN INDONESIA
}

\section{PENINGKATAN KESADARAN HUKUM MASYARAKAT DALAM MENDUKUNG PEMBANGUNAN HUKUM DAN EKONOMI DI INDONESIA*}

\author{
Ani Yunita \\ Fakultas Hukum, Universitas Muhammadiyah Yogyakarta, \\ J1. Brawijaya, Kasihan, Bantul, Yogyakarta \\ e-mail: masayunita2302@gmail.com
}

\begin{abstract}
Efforts to increase public awareness of the law are not only carried out on legal development but also on economic development, given the condition of Indonesia's economy leading to complex social problems. Referring to the above issue, the understanding towards the Indonesian people is necessary to carry out economic development in accordance with the objectives of Indonesia's economic development to increase the welfare of the community. The article aimed to investigate the efforts to increase public legal awareness in supporting legal development and economic development in order to realize welfare. The method in this research was normative juridical by using descriptive qualitative analysis. In relation, secondary data were obtained from primary legal materials, secondary legal materials and tertiary legal materials. The results proved that increasing public legal awareness in legal and economic development should be conducted by the government and all parties involved. Hence the government and law enforcement officers can proceed through counseling, legal information, assistance and guidance so that people understand the importance of legal and economic development in order to realize order, certainty, justice and community welfare.
\end{abstract}

Keywords: Improvement; Legal Awareness; Development; Law; Economy.

\section{Abstrak}

Upaya meningkatkan kesadaran hukum masyarakat tidak hanya dilakukan terhadap pembangunan hukum melainkan pembangunan ekonomi pun perlu dilakukan mengingat kondisi perkonomian Indonesia telah menimbulkan problem sosial yang kompleks. Melihat persoalan tersebut maka diperlukan suatu pemahaman terhadap masyarakat Indonesia bahwa perlunya melakukan pembangunan ekonomi sesuai dengan tujuan pembangunan ekonomi Indonesia agar meningkatnya kesejahteraan masyarakat. Tujuan penulisan artikel ini ialah untuk mengetahui upaya meningkatkan kesadaran hukum masyarakat dalam mendukung pembangunan hukum dan pembangunan ekonomi guna mewujudkan kesejahteraan rakyat. Metode yang digunakan dalam penelitian ini ialah yuridis normatif dengan menggunakan analisis deskriptif kualitatif. Jenis data yang digunakan berupa data sekunder yang diperoleh dari kepustakaan yang terdiri dari bahan hukum primer, bahan hukum sekunder dan bahan hukum tersier. Hasil dan pembahasan dalam penelitian ini bahwa peningkatan kesadaran hukum masyarakat dalam pembangunan hukum dan ekonomi perlu dilakukan oleh pemerintah dan semua pihak yang terlibat. Upaya yang dilakukan pemerintah dan aparat penegak hukum melalui penyuluhan, penerangan hukum, pendampingan dan pembinaan agar masyarakat paham mengenai pentingnya pembangunan hukum dan ekonomi guna terwujudnya ketertiban, kepastian, keadilan, dan kesejahteraan masyarakat.

Kata Kunci: Peningkatan; Kesadaran Hukum; Pembangunan; Hukum; Ekonomi.

\footnotetext{
* Naskah diterima: 3 Maret 2021, direvisi: 20 Maret 2021, disetujui untuk terbit: 27 Maret 2021

Doi: $10.3376 /$ jch.v6i2.339
} 


\section{PENDAHULUAN}

Pembangunan dapat diartikan sebagai suatu proses perubahan yang dilakukan melalui upaya-upaya secara sadar dan terencana (Riyadi \& Bratakusumah, 2005). Menurut Sondang P.Siagian memberikan pengertian pembangunan merupakan suatu usaha atau rangkaian usaha pertumbuhan dan perubahan yang berencana yang dilakukan secara sadar oleh suatu bangsa, negara dan pemerintah, menuju modernitas dalam rangka pembinaan bangsa (nation building) (Siagian, 1994). Pembangunan tersebut mencakup semua proses perubahan yang direncanakan untuk memperbaiki berbagai aspek dalam kehidupan masyarakat. Kemajuan, perbaikan, pertumbuhan dan terukur menjadi makna penting dalam proses pembangunan. Proses pembangunan terjadi dan diperlukan di semua aspek kehidupan masyarakat misalnya, hukum dan ekonomi.

Pembangunan nasional juga dapat dikatakan suatu proses yang dialami oleh masyarakat guna mendapatkan kehidupan yang lebih baik sehingga mencapai sasaran yang diharapkan dari proses pembangunan itu. Pada umumnya, kegiatan pembangunan harus terencana, terpadu dan terarah termasuk halnya dengan pembangunan hukum dan ekonomi. Dengan adanya hal tersebut, maka banyak pendapat yang mengatakan bahwa masa kini ialah hasil kumulatif dari masa yang telah lalu sedangkan masa depan akan lebih banyak ditentukan oleh upaya yang dilakukan secara bersama pada suatu bangsa. Demi terlaksananya pembangunan maka dapat dilakukan melalui suatu perubahan sosial dan budaya. Perubahan ini dapat dilakukan juga melalui pembaharuan hukum nasional (Syahbana, 2012).

Pembangunan hukum adalah upaya dalam membentuk hukum baru guna memperbarui hukum positif. Pembangunan hukum dalam konteks ini semakna dengan pembaharuan hukum. Hukum nasional merupakan hukum yang didasarkan pada Undang-Undang Dasar 1945. Pancasila sebagai dasar negara atau hukum yang dibangun di atas cita rasa dan rekayasa bangsa Indonesia. Pembangunan sistem hukum nasional mencakup pembangunan pada substansi hukum, struktur atau lembaga hukum dan budaya hukum (Arief, 2012).

Indonesia sebagai sebuah Negara Hukum (rechtstaat) yang menggunakan norma hukum sebagai sebuah guidelines dalam kehidupan berbangsa dan bernegara tentu saja mau tidak mau harus menerbitkan peraturan perundangundangan sebagai sebuah hukum positif yang berguna mengawal jalannya proses kehidupan berbangsa dan bernegara termasuk pula jalannya proses pembangunan. Pembangunan hukum di Indonesia harus berlandaskan pada landasan dan tujuan nasional serta seluruh tumpah darah Indonesia sehingga dapat memajukan kesejahteraan umum, dan mencerdaskan kehidupan bangsa (Kaelan, 2004).

Adanya berbagai macam produk peraturan perundang-undangan sendiri 
Ani Yunita: Peningkatan Kesadaran Hukum Masyarakat Dalam Mendukung...

tentunya harus diimbangi dengan pemahaman yang baik dari masyarakat, terutama masyarakat yang memiliki keterkaitan langsung dengan regulasi yang dimaksud. Untuk itulah peran penerangan hukum dan penyuluhan hukum menjadi penting dan sangat diperlukan dengan tujuan agar produk peraturan perundang-undangan dapat dipahami dengan baik dan komprehensif oleh masyarakat umum.

Atas hal tersebut, Badan Penerangan Hukum Nasional (BPHN) melalui Pusat Penyuluhan dan Bantuan Hukum, Kejaksaan Republik Indonesia melalui kegiatan Penerangan dan Penyuluhan Hukum oleh Bidang Intelijen (Kejaksaan, 2019), serta Kepolisian Republik Indonesia melalui Satuan Pembinaan Masyarakat (Sat Binmas) bersama-sama secara masif melakukan kegiatan-kegiatan penyuluhan dan penerangan hukum dengan tujuan memberikan pemahaman hukum secara utuh dan komprehensif kepada masyarakat luas.

Kesadaran hukum ialah kesadaran yang ada pada diri sendiri sehingga kesadaran tersebut muncul tanpa adanya tekanan, paksaan, atau perintah dari luar untuk tunduk pada hukum yang berlaku. Hukum tidak perlu menjatuhkan sanksi jika kesadaran hukum di masyarakat dapat berjalan di masyarakat. Sanksi hanya diberikan kepada masyarakat yang benar-benar terbukti melanggar hukum. Kesadaran hukum berkaitan dengan efektifitas hukum sehingga mengetahui jika ketentuan hukum tersebut dapat berfungsi atau tidak di dalam masyarakat (Soekanto, 1982).

Di sisi lain, ternyata pemahaman hukum masyarakat yang meningkat justru menyebabkan semakin tingginya angka kasus pidana. Dalam hal ini, tindakan dan peristiwa hukum yang terjadi di masyarakat yang seharusnya bisa diselesaikan secara baik-baik (win-win solution) tanpa harus melibatkan instrumen penegak hukum menjadi seolah-olah harus dan wajib diselesaikan lewat jalur penegakan hukum oleh aparat penegak hukum. Banyak masalah kecil yang sepele yang sebenarnya bisa diselesaikan secara baik-baik oleh para pihak terpaksa harus dibawa ke ranah meja hijau dikarenakan semakin "rajinnya" masyarakat melapor ke pihak Kepolisian setelah mereka "paham" hukum yang tidak secara komprehensif dipahami.

Menurut kacamata akademisi, hukum tidaklah semata-mata dipandang sebagai sebuah produk peraturan perundangundangan belaka, melainkan secara utuh juga mengenai ilmu (Warassih, 2005). Disiplin atau sistem ajaran tentang kenyataan, kaedah atau norma, tata hukum atau hukum positif tertulis, Keputusan Pejabat, Petugas, proses pemerintahan, perilaku yang teratur dan mempunyai jalinan nilai.

Upaya meningkatkan kesadaran hukum masyarakat juga tidak hanya dilakukan terhadap pembangunan hukum melainkan pembangunan ekonomi pun perlu dilakukan mengingat kondisi perkonomian Indonesia telah 
menimbulkan masalah sosial yang kompleks. Persoalan yang kompleks tersebut misalnya tingginya pengangguran, rendahnya produktivitas dan kualitas kinerja serta hancurnya usaha kecil dan menengah karena Indonesia tidak lagi berpihak pada ekonomi kerakyatan melainkan ekonomi yang liberal.

Melihat persoalan tersebut maka diperlukan suatu pemahaman terhadap masyarakat Indonesia bahwa perlunya melakukan pembangunan ekonomi sesuai dengan tujuan pembangunan ekonomi Indonesia agar meningkatnya kesejahteraan masyarakat. Oleh karena itu, hal tersebut diperlukan upaya dari pemerintah dan aparat penegak hukum agar kesadaran masyarakat dapat tumbuh.

Penelitian sebelumnya pernah dilakukan oleh Atang Hermawan Usman yang membahas mengenai Kesadaran Hukum Masyarakat dan Pemerintah Sebagai Faktor Tegaknya Negara Hukum di Indonesia (Hermawan Usman, 2014). Penelitian yang lain juga dilakukan oleh Moch Ali Mashuri dkk yang membahas mengenai Peran Masyarakat Terhadap Pembangunan Ekonomi Berbasis Kampung Tangguh Sebagai Upaya Menekan Angka Covid-19 Di RT 04 RW 14 Kelurahan Kalirungkut Kota Surabaya (Mashuri et al., 2020). Sedangkan pada penelitian peneliti lebih membahas mengenai Peningkatan Kesadaran Hukum Masyarakat Dalam Mendukung Pembangunan Hukum dan Ekonomi Di Indonesia.
Berdasarkan fakta-fakta yang telah diuraikan sebelumnya maka untuk mendukung pembangunan hukum dan ekonomi di Indonesia diperlukan upaya untuk memberikan pemahaman kepada masyarakat secara komprehensif guna mendukung proses pembangunan nasional demi terwujudnya ketertiban, kepastian, keadilan, dan kesejahteraan rakyat Indonesia.

Berdasarkan latar belakang diatas maka perumusan masalahnya ialah untuk mengkaji bagaimana upaya meningkatkan kesadaran hukum masyarakat dalam mendukung pembangunan hukum Indonesia dan bagaimana upaya meningkatkan kesadaran hukum masyarakat dalam mendukung pembangunan ekonomi guna mewujudkan kesejahteraan rakyat.

\section{METODE PENELITIAN}

Jenis/tipe dalam usulan penelitian hukum yang digunakan penulis adalah penelitian yuridis normatif. Penelitian normatif merupakan penelitian yang dilakukan dengan cara mempelajari bahan hukum seperti peraturan perundangundangan, buku-buku, makalah-makalah, publikasi ilmiah yang berkaitan dengan masalah yang diteliti.

Penelitian ini menggunakan sumber data sekunder berupa penelitian kepustakaan. Penelitian kepustakaan ialah penelitian yang dilakukan berdasarkan pada buku-buku, literaturliteratur yang berkaitan dengan masalah yang akan diteliti. Penelitian kepustakaan ini dilakukan pada Perpustakaan Fakultas 
Ani Yunita: Peningkatan Kesadaran Hukum Masyarakat Dalam Mendukung...

Hukum UNDIP dan Perpustakaan Fakultas Hukum UMY.

Jenis data yang digunakan ialah berupa data sekunder yang diperoleh dari kepustakaan yang terdiri dari bahan hukum primer, bahan hukum sekunder dan bahan hukum tersier.

Teknik pengumpulan data yang digunakan oleh peneliti untuk memperoleh sumber data sekunder yakni melalui pengumpulan data dengan pengamatan dan penelusuran studi pustaka.

Metode analisis data yang digunakan dalam penelitian ini adalah analisis deskriptif kualitatif, yaitu menganalisa data dengan menguraikan gejala atau fenomena dan fakta-fakta yang didapat di lapangan secara objektif untuk menjawab permasalahan penelitian.

\section{HASIL DAN PEMBAHASAN}

\section{Peningkatan Kesadaran Hukum Masyarakat Dalam Mendukung Pembangunan Hukum Indonesia}

Pembangunan diartikan sebagai suatu proses perubahan sosial dengan partisipatori yang luas dalam suatu masyarakat yang dimaksudkan untuk mencapai kemajuan sosial dan material (termasuk bertambah besarnya keadilan, kebebasan dan kualitas lainnya yang dihargai) untuk mayoritas rakyat melalui pengawasan yang lebih besar terhadap lingkungan mereka. Pada hakekatnya pembangunan harus mencerminkan perubahan total suatu masyarakat atau penyesuaian sistem sosial secara keseluruhan, tanpa mengabaikan keragaman kebutuhan dasar dan keinginan individual maupun kelompokkelompok sosial yang ada di dalamnya, untuk bergerak maju menuju suatu kondisi yang lebih baik, secara material maupun spiritual (Henry, 2014).

Pembangunan hukum merupakan tindakan atau kegiatan yang dimaksudkan untuk membentuk kehidupan hukum ke arah yang lebih baik dan kondusif. Pembangunan hukum harus terintegrasi dan bersinergi dengan pembangunan bidang lain, serta memerlukan proses yang berkelanjutan. Pelaksanaan pembangunan hukum semestinya tidak hanya ditujukan untuk hukum dalam arti positif. Hukum tidak hanya diartikan/ identik dengan peraturan perundangundangan, tetapi juga hukum dalam arti yang luas yaitu hukum yang menunjuk pada sebuah sistem. Hukum yang meliputi pembangunan materi hukum, pembangunan kelembagaan dan penegakan hukum, pembangunan pelayanan hukum dan pembangunan kesadaran hukum masyarakat. Unsurunsur tersebut saling mempengaruhi maka hukum harus dibangun secara simultan, sinkron, dan terpadu.

Suatu hal yang harus diperhatikan bahwa pembangunan di bidang hukum harus berdasar atas landasan cita-cita yang terkandung pada pandangan hidup, kesadaran dan cita-cita moral yang luhur yang meliputi suasana kejiwaan serta watak dari bangsa Indonesia yang ditemukan dalam Pancasila dan UUD NRI 1945. Hukum sebagai perwujudan nilai-nilai mengandung arti bahwa 
kehadirannya adalah untuk melindungi dan memajukan nilai-nilai yang dijunjung tinggi oleh masyarakatnya (Hamzani et al., 2018).

Kesadaran hukum merupakan konsepsi abstrak di dalam diri manusia, tentang keserasian antara ketertiban dan ketentraman yang dikehendaki atau sepantasnya. Kesadaran hukum sering dikaitkan dengan pentaatan hukum, pembentukan hukum, dan efektivitas hukum. Kesadaran hukum merupakan kesadaran/nilai-nilai yang terdapat dalam manusia tentang hukum yang ada atau tentang hukum yang diharapkan oleh masyarakat luas (Rosana, 2014).

Peningkatan kesadaran hukum masyarakat dapat dilakukan dengan melalui beberapa cara antara lain meningkatkan akses kepada masyarakat baik mengenai segala informasi yang dibutuhkan maupun dalam proses pengambilan keputusan pelaksanaan pembangunan nasional. Selain itu, kesadaran hukum masyarakat juga akan meningkat jika didukung dengan pelayanan yang baik dengan biaya yang terjangkau, proses yang tidak berbelit, dan mencerminkan rasa keadilan. Dengan demikian, setiap warga negara harus menyadari dan menghayati hak dan kewajibannya.

Upaya meningkatkan kesadaran hukum masyarakat dilakukan melalui penyuluhan dan penerangan hukum yang merupakan bagian tugas dari Badan Pembinaan Hukum Nasional (BPHN). BPHN berdiri pada tanggal 30 Maret 1958. BPHN semula bernama Lembaga
Pembinaan Hukum Nasional (LPHN) yang dibentuk berdasarkan Keputusasn Presiden RI No. 107 tahun 1958. (BPHN, 2019)

Penyuluhan hukum merupakan bagian dari pembangunan hukum nasional, sedangkan pembangunan hukum nasional bagian dari pembangunan nasional. Kegiatan penyuluhan hukum merupakan salah satu sosialisasi untuk menggambarkan mengenai keadilan dapat tercipta. Peranan hukum sebagai alat Pembangunan masyarakat sebagaimana dikemukakan oleh Roscoe Pound perlu ditempatkan pada persepsi yang disepakati bersama untuk memahami sifat, hakikat dan konsekuensi diterimanya suatu konsepsi. Apabila hukum diberi peranan sebagai sarana perubahan dan pembangunan, maka pemikiran ini membuktikan adanya kesadaran terhadap pengaruh timbal balik antara hukum dan masyarakat (Sudjana, 2016).

Esensi untuk memberikan kemampuan mengenai pemahaman hukum dengan cara meningkatkan sikap sadar akan hukum kepada masyarakat. Oleh karena itu, masyarakat bisa membedakan antara perbuatan yang diperbolehkan atau tidak. Tingkat kesadaran dan kepatuhan terhadap hukum itu sendiri dapat menjadi parameter suatu kemajuan bangsa. Apabila tingkat kesadaran hukum meningkat maka akan tercapainya ketertiban, keadilan dan ketertiban masyarakat.

Terciptanya budaya hukum masyarakat yaitu melalui cara dengan 
Ani Yunita: Peningkatan Kesadaran Hukum Masyarakat Dalam Mendukung...

meningkatkan profesionalisme aparat penegak hukum dan birokrasi. Profesionalisme ini akan sangat berpengaruh terhadap kepercayaan masyarakat terhadap hukum itu sendiri. Selain itu, untuk meningkatkan kesadaran hukum yaitu dengan mempelajari pengetahuan tentang hukum secara utuh baik terhadap peraturan yang tertulis (terkodifikasi) maupun peraturanperaturan yang tidak tertulis. Membangun budaya hukum masyarakat merupakan bagian dari upaya nation character building. Oleh karena itu, Pemerintah harus membangun sikap dan mengubah mental bangsa karena masyarakat selama ini cenderung berpikiran negatif sehingga bangsa Indonesia cenderung masih toleran terhadap pelanggaran-pelanggaran hukum.

Pengetahuan hukum bertujuan untuk mengetahui hukum yang mengatur perilaku manusia di dalam masyarakat, mengetahui perilaku-perilaku yang dilarang dan diperbolehkan oleh hukum, serta mengetahui sanksi apabila melanggar hukum. Dengan demikian, seseorang dapat menilai bahwa hukum tersebut dikatakan baik apabila hukum tersebut telah sesuai dengan nilai-nilai yang ada di dalam masyarakat (Sumaryati, 2016).

\section{Peningkatan Kesadaran Hukum Masyarakat Dalam Mendukung Pembangunan Ekonomi guna Mewujudkan Kesejahteraan Masyarakat}

Hubungan hukum dengan ekonomi bukan hubungan satu arah, tetapi hubungan timbal balik dan saling mempengaruhi. Kegiatan ekonomi yang tidak didukung oleh hukum, maka akan mengakibatkan terjadi kekacauan di negara Indonesia. Apabila para pelaku ekonomi dalam mengejar keuntungan tidak dilandasi dengan norma hukum, maka akan menimbulkan kerugian pada salah satu pihak dalam melakukan kegiatan ekonomi. Setiap kegiatan ekonomi yang dilakukan tentunya kegiatan itu diikuti oleh norma hukum yang menjadi ketentuan pelaksananya. Hukum yang mengikuti kegiatan ekonomi ini ialah seperangkat norma yang mengatur hubungan kegiatan ekonomi dan dipengaruhi oleh sistem ekonomi yang dianut oleh suatu negara. Dasar kegiatan hukum ekonomi Indonesia berlandaskan pada Pasal 33 UUD 1945 dan beberapa peraturan derivatif lainnya (Manan, 2014).

Roscoe Pound menyatakan bahwa hukum dianggap sebagai alat rekayasa sosial apabila hukum yang berkembang dalam masyarakat dapat berperan dan berfungsi sebagaimana mestinya. Misalnya, hukum dalam hal ini berpengaruh pada pembangunan ekonomi (Suhardi, 2002). Pembangunan ekonomi dan hukum tentunya harus beriringan agar fungsi dan peran hukum dapat mengakomodir ketentuan-ketentuan dalam bidang perekonomian. Sebagai contoh, Indonesia tidak dapat menutup diri dari era pasar global karena hal tersebut untuk menunjang perekonomian nasional Indonesia sehingga ketentuan yang disepakati secara internasional dapat 
diakomodir oleh ketentuan hukum di Indonesia.

Kesadaran hukum terbentuk dari persoalan "hukum sebagai perilaku" dan bukan "hukum sebagai aturan norma atau asas". Dengan demikian, masyarakat memerlukan institusi untuk memenuhi kebutuhan dan memperlancar jalannya pemenuhan kebutuhan tersebut. Kesadaran hukum masyarakat bukan berarti harus berkaitan dengan ketaatan hukum masyarakat akan tetapi ketaatan hukum merupakan "kesetiaan" seseorang atau subyek hukum terhadap hukum yang diwujudkan dalam bentuk perilaku yang nyata (Rahardjo, 2003).

Membangun masyarakat yang sadar hukum terutama pada hukum ekonomi merupakan hal penting yang diharapkan akan membentuk dan menjadikan masyarakat menjunjung tinggi institusi/aturan sebagai pemenuhan kebutuhan dan pengharapan akan ketaatan dan ketertiban (Utomo, 2018). Upaya Pemerintah dan aparat penegak hukum yaitu harus berperan aktif dalam mengakomodasi kesadaran hukum. Upaya yang dapat dilakukan melalui penyuluhan dan penerangan hukum dengan melakukan pendekatan-pendekatan yang sesuai dengan jiwa dan budaya bangsa antara lain sebagai berikut:

a. Mendorong seluruh lapisan masyarakat baik itu pengusaha maupun konsumen agar dapat berperan aktif dalam mengikuti kegiatan ekonomi. Masyarakat harus mendapatkan perlindungan hukum agar hak masyarakat mendapatkan perlindungan dari negara.

b. Upaya meningkatkan usaha-usaha kecil/ mikro, mengurangi kemiskinan dan pemberdayaan usaha mikro, kecil dan menengah.

c. Pemerintah perlu melakukan intervensi guna menciptakan iklim persaingan usaha yang sehat sesuai dengan ketentuan hukum persaingan usaha yang sehat.

d. Memberikan kemudahan kepada pelaku usaha mikro kecil dan menengah dengan menumbuhkan pasar yang kompetitif sehingga menstimulasi UMKM untuk dapat selalu survive dalam menjalankan kegiatan ekonomi.

e. Memprioritaskan pembangunan ekonomi pedesaan, daerah tertinggal, terdepan, dan terluar dan termasuk daerah terbelakang lainnya.

Dengan memperhatikan dan melakukan pendampingan kepada pelaku Usaha Mikro, Kecil dan Menengah (UMKM) dalam kaitannya kegiatan ekonomi maka pemahaman masyarakat mengenai ekonomi kerakyatan bisa diterapkan sehingga pelaku ekonomi berskala kecil akan lebih meningkat. Selain kegiatan ekonomi, pendekatan sistem ekonomi menganut demokrasi ekonomi juga perlu selalu dikembangkan sehingga dalam segala kegiatan ekonomi akan memperhatikan demokrasi ekonomi. Sistem ekonomi kerakyatan dapat diartikan sebagai upaya perlibatan seluruh lapisan masyarakat sebagai motor penggerak pembangunan nasional. 
Ani Yunita: Peningkatan Kesadaran Hukum Masyarakat Dalam Mendukung...

Dengan demikian, prinsip-prinsip demokrasi ekonomi dapat diimplementasikan dengan baik untuk mendorong pembangunan nasional (Yasin, 2002).

Kesejahteraan rakyat Indonesia ialah hasil dari penerapan ekonomi kerakyatan yang melibatkan semua masyarakat sehingga keadilan, demokrasi ekonomi, dan keberpihakan pada ekonomi rakyat dapat terwujud. Meskipun negara Indonesia masih sangat jauh untuk disebut sebagai negara kesejahteraan, namun masyarakat memiliki kesepakatan bersama dan semangat untuk mewujudkannya. Pancasila dan Pasal 27 ayat (2), 28, 31, 33 dan Pasal 34 UndangUndang Dasar Negara Republik Indonesia 1945 merupakan landasan hukum yang sangat tepat sesuai dengan amanat founding fathers Bangsa Indonesia. Pancasila sebagai landasan ideologis serta sistem nilai suatu bangsa, sehingga dapat mewujudkan keadilan sosial.

Pembangunan sektor ekonomi masyarakat perlu diwujudkan oleh agar terciptanya kesejahteraan masyarakat. Pembangunan ekonomi agar dapat tumbuh dan berkembang jika didukung oleh organisasi dan partisipasi masyarakat yang memiliki kapasitas, kapabilitas, dan kinerja dalam kehidupan masyarakat yang baik (Nugraha, 2009).

Pesatnya pertumbuhan dan perkembangan ekonomi baik secara nasional maupun internasional menyebabkan lahirnya hukum ekonomi. Hukum sebagai alat untuk mengatur dan membatasi kegiatan-kegiatan ekonomi, dengan tujuan agar perkembangan perekonomian tersebut tidak merugikan hak-hak dan kepentingan masyarakat. Dengan demikian, hukum itu tidak hanya berupa pengaturan terhadap aktivitas ekonomi, tetapi juga bagaimana pengaruh ekonomi terhadap hukum (Manan, 2014).

Peningkatan taraf hidup masyarakat di Indonesia diperlukan sebagai upaya guna mendorong masyarakat dalam meningkatkan iklim investasi. Hal tersebut dilakukan untuk menghindari ketertinggalan dengan negara-negara lain sehingga pembangunan ekonomi perlu diwujudkan. Namun demikian, hal ini harus sejalan dan selaras dengan pembangunan hukum di Indonesia yang memadai sehingga welfare state dapat terwujud.

Selain itu, dengan adanya landasan hukum yang kuat dapat mendukung terciptanya pembangunan ekonomi. Ekonomi merupakan tulang punggung kesejahteraan rakyat, dan ilmu pengetahuan adalah tiang-tiang penopang kemajuan bangsa sebagaimana dengan pernyataan Ismail Saleh. Namun, tidak dapat disangkal bahwa hukum merupakan pranata yang menentukan terwujudnya kesejahteraan rakyat secara merata, keadilan sosial masyarakat, kemajuan ilmu pengetahuan dan teknologi yang dapat meningkatkan kemajuan masyarakat (Sukardi, 2016).

\section{SIMPULAN}

Berdasarkan pembahasan diatas maka dapat disimpulkan bahwa hukum, masyarakat dan pembangunan memiliki 
keterkaitan dan ketergantungan diantara satu dengan yang lainnya. Peningkatan kesadaran hukum masyarakat dalam pembangunan hukum di Indonesia yaitu melalui program penyuluhan dan penerangan hukum. Program tersebut dilakukan sebagai upaya pemerintah dan aparat penegak hukum agar kesadaran hukum masyarakat terhadap pembangunan hukum dapat dipahami secara komprehensif. Dengan adanya kondisi masyarakat yang harmonis dan teratur maka penyelenggaraan pembangunan dapat berjalan dengan baik dan lancar sehingga dapat mewujudkan ketertiban, kepastian, dan keadilan, masyarakat.

Peningkatan kesadaran hukum masyarakat dalam pembangunan ekonomi juga perlu dilakukan oleh pemerintah dan semua pihak yang terlibat. Upaya yang dapat dilakukan oleh pemerintah dan aparat penegak hukum ialah melalui penyuluhan, penerangan hukum, pendampingan dan pembinaan. Upaya tersebut dilakukan agar masyarakat dapat memahami mengenai pentingnya pembangunan ekonomi guna terwujudnya kesejahteraan masyarakat.

\section{DAFTAR PUSTAKA}

Arief, B. N. (2012). Pembangunan Sistem Hukum Nasional. Pustaka Magister.

BPHN, T. (2019). Badan Pembina Hukum Nasional.

https://bphn.go.id/readinfo/main_his tory

Hamzani, A. I., Mukhidin, \& Rahayu, D. P. (2018). Pembangunan Hukum Nasional Sebagai Implementasi
Tujuan Nasional. Prosiding

SENDI_U, 1(3), 366-372.

Henry. (2014). Partisipasi Masyarakat Dalam Perencanaan Pembangunan (Studi Kasus Pada Kecamatan Sidikalang Kabupaten Dairi). Jurnal Administrasi Publik, Volume 2(Desember 2014), 118.

Hermawan Usman, A. (2014). Kesadaran Hukum Masyarakat Dan Pemerintah Sebagai Faktor Tegaknya Negara Hukum Di Indonesia. Jurnal Wawasan Yuridika, 30(1), 26-53.

Kaelan. (2004). Pendidikan Pancasila. Paradigma.

Kejaksaan, T. (2019). Kejaksaan RI. https://www.kejaksaan.go.id/unit_k ejaksaan.php?idu=29

Manan, A. (2014). Peran Hukum Dalam Pembangunan Ekonomi. Prenada Media Group.

Mashuri, M. A., Aprilina, S. D., \& Nahdiyah, V. (2020). Peran Masyarakat Terhadap Pembangunan Ekonomi Berbasis Kampung Tangguh Sebagai Upaya Menekan Angka Covid-19 Di Rt 04 Rw 14 Kelurahan Kalirungkut Kota Surabaya. Jurnal Manajemen \& Kewirausahaan, 5(2), 141-156. http://ejournal.unira.ac.id/index.php /jurnal_makro_manajemen/article/vi ew/961

Nugraha, A. (2009). Pengembangan Masyarakat Pembangunan Melalui Pendampingan Sosial Dalam Konsep Pemberdayaan Di Bidang Ekonomi. Jurnal Ekonomi Modernisasi, $\quad 5, \quad 10$. http://ejournal.ukanjuruhan.ac.id 
Ani Yunita: Peningkatan Kesadaran Hukum Masyarakat Dalam Mendukung...

Rahardjo, S. (2003). Sisi-Sisi Lain Dari Hukum di Indonesia. Penerbit Buku Kompas.

Riyadi, \& Bratakusumah, D. S. (2005). Perencanaan Pembangunan Daerah;Strategi Menggali Potensi Dalam Mewujudkan Otonomi Daerah. Gramedia Pustaka Utama.

Rosana, E. (2014). Kepatuhan Hukum Sebagai Wujud Kesadaran Hukum Masyarakat. Jurnal TAPIs, 10(1), $1-25$.

Siagian. (1994). Administrasi Pembangunan. Bumi Aksara.

Soekanto, S. (1982). Kesadaran Hukum dan Kepatuhan Hukum. Rajawali.

Sudjana. (2016). Penyuluhan Hukum Dalam Upaya Peningkatan Kesadaran Hukum Berlalulintas Melalui Pemahaman Terhadap. Jurnal Pendidikan Ilmu Sosial, 25(2), 1-14. https://ejournal.upi.edu/index.php/jp is/issue/view/702

Suhardi, G. (2002). Peranan Buku Dalam Pembangunan Ekonomi. Universitas Atma Jaya.

Sukardi, (2016). Peran Penegakan Hukum Dalam Pembangunan Ekonomi. Jurnal Hukum \& Pembangunan,
46(4),

434-453. https://doi.org/10.21143/jhp.vol46.n 04.48

Sumaryati. (2016). Urgensi Pendidikan Hukum Dalam Mewujudkan Kesadaran Hukum Masyarakat.

Syahbana, T. E. (2012). Sistem Hukum Perkawinan Pada Negara Hukum Berdasarkan Pancasila. Ilmu Hukum, 3(1), 5.

Utomo, P. (2018). Membangun Kesadaran Hukum Masyarakat Menuju Green City. Nurani Hukum, l(1), 11. https://doi.org/10.51825/nhk.v1i1.4 812

Warassih, E. (2005). Pranata Hukum Sebuah Telaah Sosiologis. PT. Suryandaru Utama.

Yasin, Z. F. (2002). Usaha Kecil dan Koperasi Berwawasan Ekonomi Kerakyatan. Unri Press. 